\title{
Framing the Philpotts: Anti-welfarism and the British newspaper reporting of the Derby house fire verdict
}

\section{ABSTRACT}

This article analyses the newspaper reporting of the Mick Philpott manslaughter verdict of 2013. Philpott is an unemployed British man who in May 2012 set fire to his house, accidentally killing six children. This article argues that the Philpott verdict provided a valuable propaganda opportunity for British politicians and elements of the British media to link the crime to 'welfare reform' at a time when the coalition government had begun to target welfare benefits for cuts. In particular, it is argued that the demonization of Philpott as a member of the white British underclass converged with an intensification of conservative and anti-welfarist arguments about the United Kingdom's benefits system, reviving and reinforcing the Victorian concept of the 'undeserving poor' and the related notion that benefits are a reward for good behaviour rather than a right. Examining articles from national newspapers published in the days following the announcement of a guilty verdict in the trial, this article analyses the discursive framing of the stories in order to discover what kind

14. of ideological messages were at work in the reporting of the Philpott verdict and

\section{KEYWORDS}

anti-welfarism benefits system ideology Mick Philpott newspapers propaganda United Kingdom 
what sorts of differences existed between these messages. The article concludes with an attempt to set this analysis in a wider socio-political context, considering how the press's perspectives on the story relate to the ideological (re)framing of public discussion about welfare 'benefits' and claimants in the United Kingdom today.

\section{INTRODUCTION}

This article analyses the newspaper reporting of the Mick Philpott manslaughter verdict of 2013. Philpott is a British man who in May 2012 set fire to his house, accidentally killing his children. He had planned to 'rescue' the children from the fire, painting himself as a hero and blaming the fire on his former partner, Lisa Willis, who had lived with Philpott and his wife Mairead in a ménage-a-trois until she left the household in 2012, much to Philpott's annoyance. Had his plan succeeded, Philpott could have gained custody of Lisa's children and thereafter accessed increased social security payments. Mairead Philpott and a family friend, Paul Mosley, had known about Philpott's scheme. In the days and weeks following the tragedy, however, all three individuals maintained the pretence that they were innocent of the crime, although police had apparently suspected their involvement from the outset. After a high-profile court trial, Philpott, along with Mairead and Mosley, was found guilty of manslaughter and given a prison sentence on 3 April 2013. Many reports about Mick Philpott's history of brutality and sexual violence towards women began to emerge after the trial ended and legal restrictions on reporting were lifted.

The Philpott story was phenomenally newsworthy, containing many of British journalism's core 'news values', including drama, novelty and titillation (Chibnall 1977). The Philpotts' indulgence in drug-taking, 'dogging' and polyamory, in particular, made their story high priority for a British tabloid press ever eager to report tales of sexual irregularity (Conboy 2005: 123-51). The identities of the dramatis personae added to the story's newsworthiness. As Pritchard and Hughes (1997:49) have argued in relation to the US context, homicides are more likely to be reported by journalists when 'Whites are suspects or victims, males are suspects, and victims are females, children or senior citizens', aly of which pertained in this case, while murders of women are considered more 'deviant' than murders of men and hence more deserving of attention) (1997: 53). Perhaps the most scandalous aspect of the Philpott story, however, was the performance of Philpott and his wife at a press conference following the fire, in which the couple had pretended to be the victims of an arsonist. As Chermak (1995: 2) notes, 'the newsworthiness of [...] crime increases significantly if members of the family weep on camera, provide a descriptive photograph, or express their pain dramatically in words'. The Philpotts certainly did this; but after the trial, it became clear that the couple's expressions of grief, if not cynically acted out for the cameras, had been masking their responsibility for their children's deaths. Little wonder, perhaps, that the Philpotts - and Mick, in particular - became publically hated figures.

But there was another factor that contributed to Mick Philpott's notoriety. By the time of the house fire trial, Philpott was already a minor television celebrity - or perhaps anti-celebrity - in the United Kingdom. His large number of children (Philpott had fathered seventeen children by 2013) and his unusual lifestyle (sharing a house with his wife and a girlfriend), as well
1.

2.

3.

4.

5.

6.

7.

8.

9.

10.

11.

12.

13.

14.

15.

16.

17.

18.

19.

20.

21.

22.

23.

24.

25.

26.

27.

28.

29.

30.

31.

32.

33.

34.

35.

36.

37.

38.

39.

40.

41.

42.

43.

44.

45.

46.

47.

48.

49.

50.

51.

52. 
as his 2006 request for a larger council house for his then eleven children, earned him appearances on several ITV television programmes, including the talk show The Jeremy Kyle Show, the breakfast programme This Morning, and a 2007 documentary fronted by the Conservative MP Ann Widdecombe entitled Ann Widdecombe Versus the Benefits Culture. In each of these appearances, Philpott was quizzed by the presenters about his 'irresponsible' lifestyle. Long before he was found guilty of manslaughter, therefore, Philpott had become emblematic of the feckless British 'benefits scrounger', one who 'contributes' nothing to 'the economy' and takes resources from hard-working, taxpaying others. For the right-wing journalist Amanda Platell (2006: 17) - one of Philpott's most dedicated scourges - Philpott represented a 'growing underclass of rootless, hopeless, white working-class boys who are causing ever-growing problems in Britain today'. In sociological terms, Philpott thus came precoded as a 'folk devil' (Cohen 1972), or - in Imogen Tyler's (2012) more recent coinage - a 'national abject' to rival the illegal immigrant, the 'chav' and the gypsy.

As Chris Haylett (2001: 355) notes, 'welfare is a divisive apparatus, made so by its political caretakers'. The figure of the 'benefits scrounger' has long been a staple of British political and media discourse. Writing in The Road to Wigan Pier in 1937, George Orwell (quoted in Jones 2012: 13) lamented that the notion that the working class have been absurdly pampered, hopelessly demoralized by doles, old-age pensions, free education, etc. [...] is still widely held'. The virulence of these cultural images of the scrounger arguably lessened in the middle years of the twentieth century; but in the 1970s, scare stories about scroungers began to assume an increasingly central role in political discourse (Deacon 1978). In the late 1970s, as Thatcherism sought to roll back the welfare state, Stuart Hall et al. (1979: 17) argued that the figure of the 'welfare "scavenger"' was being rehabilitated in the British cultural imaginary as part of a bid to enforce an anti-collectivist 'common sense'; this had the effect of creating a 'moral panic' around supposed welfare abuses (Golding and Middleton 1982). Since this period, the figure of the 'celebrity scrounger' or 'super-scrounger' has become a familiar one. Writing in the late 1990s, Peter Golding (1999: 149) noted that the 'pig farmer and invalidity beneficiary' Paul Booth became a figure of hatred in the British press in 1998; in terms that anticipate the media coverage of Mick Philpott, Booth was lacerated in The Sun as an example of 'layabouts who do nothing but breed'.

These divisive discourses recrudesced in the UK after the election of Conservative-Liberal Democrat government in 2010. The new government's proposals to cut back on social welfare - part of a panoply of measures, including the introduction of a controversial 'workfare' scheme, designed to reduce a substantial deficit - were accompanied by numerous statements from Conservative Party politicians that raised questions about the genuineness of many benefit claims. As Kayleigh Garthwaite (2011: 370) notes in relation to official pronouncements about Incapacity Benefit (IB):

When discussing the latest proposals, Department for Work and Pensions secretary Iain Duncan Smith recently claimed that 'most people in Britain are honest, straight, hardworking'. Therefore, the underlying suggestion is that there are people receiving benefits who are in fact the opposite: dishonest, dodgy, and workshy. Indeed, David Cameron stated that if people 'really cannot work', then they will be looked after. However, it is the insertion of 'really' that belies scepticism about the truth of whether people really can or cannot work. 
This article argues that the Philpott verdict constituted a valuable propaganda opportunity for British politicians and elements of the British media to exploit these kinds of suspicions about the genuineness of welfare claims at a time when the coalition government had begun to target a range of welfare benefits for cuts. In particular, it is argued here that the demonization of Philpott converged with an intensification of conservative and anti-welfarist arguments about the United Kingdom's benefits system, reviving and reinforcing the Victorian concept of the 'undeserving poor' and the related notion that benefits are a reward for good behaviour rather than a right. It should be made clear at the outset, however, that there is no question here of defending Philpott's criminal actions or his deplorable history of violence against women; the point, rather, is to show how his crime was reported by a certain section of the British press in ways that tended to reinforce an anti-welfarist agenda.

This article undertakes a qualitative analysis of stories from British newspapers with a range of political affiliations and is based on articles obtained through the databases ukpressonline and Nexis. Comparing articles from national newspapers published in the days following the announcement of a guilty verdict in the trial (3 April 2013), it analyses the discursive framing of the stories in order to discover what kind of ideological messages were at work in the reporting of the Philpott, verdict and what sorts of differences existed between these messages. To frame an issue in the media is, in Entman's classic formulation,

to select some aspects of a perceived reality and make them more salient in a communicating text, in such a way as to promote a particular problem definition, causal interpretation, moral evaluation and/or treatment recommendation for the item described.

(Entman 1993: 52)

It is argued here that the conservative press consistently sought to highlight Philpott's status as a benefits claimant and to connect this to his crime, highlighting both Philpott's moral depravity and, in turn, the need for 'reform' of the benefits system. The article concludes with an attempt to set this analysis in a wider socio-political context, considering how the press's perspectives on the story relate to the ideological (re)framing of public discussion about welfare 'benefits' (itself, of course, a term freighted with moral and ideological assumptions about entitlement and desert) and claimants in the United Kingdom today?

\section{ANALYSIS}

Britain's conservative press displayed a largely consistent approach to the Philpott case. For many conservative commentators, Mick Philpott was sometimes described simply as 'scum' (Ferrari 2013: 25), a word that had been hurled at the Philpotts by the public during the trial and which has become the pejorative of choice to describe unruly elements of the British working class (Tyler 2012: 180-81). Even more commonly, Philpott was described as 'evil'. On the day of the guilty verdict, the Daily Express front page read ' 6 Angels Killed by Evil Parents' (Jeeves 2013a) - a headline that typifies the Manichean moralism of the tabloid press (Gripsrud 1992; Conboy 2005: 16). The story is accompanied by photographs of Philpott and his wife smiling; an obscene detail in view

1. 2. 3. 4. 5. 6. 7. 8. 9. 10. 11. 12. 13. 14. 15. 16. 17. 18. 19. 20. 21. 22. 
of the crimes for which the pair were responsible. For The Express, the characterization of Philpott as both 'evil' and a 'scrounger' is paramount: indeed, the very first words of the front-page story are: 'Britain's most evil scrounger Mick Philpott faces life behind bars for killing his six children in a desperate bid to get an extra $£ 1,000$ a month in hand-outs'. Avoiding the arguably more neutral and bureaucratic term 'unemployed', the second paragraph of the story calls Philpott 'jobless' and ends with the statement that Philpott 'wanted custody of five other children he fathered so he [sic] could rake in more cash'. The disparaging terms 'hand-out', 'rake in' and - arguably - 'jobless' draw attention to Philpott's status as an unemployed benefit claimant in a derogatory manner. Philpott's distasteful behaviour following the crime is also highlighted: it is noted, for example, that there were reports of Philpott singing an Elvis song during a karaoke session in his local public house just days after the deaths of his children.

The Express's front-page story is followed by a double-page spread on pages 4 and 5 entitled 'Killer dad started blaze so he could get more benefits' (Jeeves 2013b: 4-5). The accompanying photographs here are of the Philpotts on their wedding day, captioned 'wicked couple', and of the couple hugging in their kitchen. As its title suggests, the spread also makes much of the Philpotts' benefit claims and the tone is generally moralistic; for instance, a subheading on page 4 comprises the single word 'Depraved', while the stories on page 5 each begin by prefixing Philpott's name with a judgemental adjective, which imply immorality ('Shameless Mick Philpott') and psychological disorder or mental illness ('Crazed Mick Philpott') - an association of 'evil' or wrongdoing with mental illness that could be argued to contribute to longstanding negative stereotypes of people suffering from mental distress (Wahl 1995).

A feature of the Express coverage is its focus on Philpott's background as a long-time beneficiary of his wife and girlfriend's welfare benefits. The demonization of benefit claimants became a widespread tabloid script in the wake of the verdict. The 6 April editorial of Britain's pre-eminent right-wing tabloid, the Daily Mail, for example, called for an end to what it termed the 'culture of welfarism and greed'. Elsewhere in the same edition of the Daily Mail, conservative columnist Amanda Platell (2013) wrote:

The Chancellor knew he would be ambushed by the BBC and vilified by the Left, yet he also knew taxpayers who fund benefit scroungers like Philpott have had enough. For while it is true that Shameless Mick is a uniquely evil, exploitative individual, he is also the product of a far wider problem. As a result of his crimes, the debate people want about the welfare system is finally out in the open.

Here, Platell links Philpott's criminality to his status as a benefits claimant, with the implication that there is a connection (whether causal or correlational) between the two conditions. In her ad populum appeal to 'the debate people want', Platell also implies that her point of view is shared by many, if not all, people. In both their content and their form, therefore, Platell's arguments are consistent with the British Chancellor George Osborne's recommendation that the Philpott case should be linked to a debate about welfare and that 'the majority of the country' shared his views.

Similar arguments were in evidence in Britain's most-read tabloid newspaper, The Sun - a newspaper which had some years previously been criticized for using misleading figures in an attempt to exaggerate the scale 
of benefit fraud in the United Kingdom (Hancock and Mooney 2011: 27). 1. The Sun's editorial on the day of the Philpott verdict ('In the gutter' 2013: 8) 2. stated that 'we' had all supported Philpott financially - the first person plural pronoun here invoking what Conboy (2005: 16) terms the 'linguistics of consensus': 'It's hard to imagine a more repulsive creature than Mick Philpott, the lowlife benefits scrounger convicted of killing six of his children in a fire. And who paid for his disgusting lifestyle? We did'. Moreover, like Platell and the Daily Mail, The Sun editorial proposes that there is a link - in this instance a causal one - between being on benefits and moral turpitude: 'When benefits are so generous, easily obtainable and dished out indiscriminately, they can debase humanity'. For much of the tabloid press, then, the Philpott case showed the need for 'welfare reform' at a moment when the ConservativeLiberal Democrat government was in the process of implementing cuts to a variety of social security benefits.

Yet it was not only the tabloids that exploited the Philpott tragedy in order to promote the coalition government's agenda on benefits. In the right-wing broadsheet The Daily Telegraph, for example, Allison Pearson (2013) wrote a column whose title - 'Mick Philpott, a good reason to cut benefits' - implied that the Philpott case should be taken as a vindication of the government's welfare reduction plans. But it was Camilla Cavendish's (2013) article in the conservative Times, with its audacious subtitular assertion that 'The benefits system entrenches people in unemployment and unwittingly encourages them to lie, cheat and have big families', that most explicitly identified the welfare system as a cause of immorality, adding into the mix a neo-Malthusian swipe at working class over-reproduction.

By presenting Philpott as (banally) 'evil' and a 'monster', the conservative press transcoded the Philpott story into a moral fable about a wicked and lazy man who, corrupted by an unduly generous welfare system, made poor 'lifestyle choices' (including that of having 'too many' children). This account of the Philpott story takes its coordinates from the discourse of 'neoliberal' individualism, with its neo-Victorian assumption that benefits constitute a reward to be dispensed to the 'deserving poor' rather than a right guaranteed by the welfare state. What such an account elides, moreover, are the structural issues raised by the Philpott case, such as domestic violence and the inadequacy of childcare provision, as well as the issues of poverty and low wages and, indeed, of low benefit levels: after all, the total sum of benefits being claimed by Philpott at the time of his crime was very small given the large size of Philpott's family. At the same time, the conservative press presented Philpott as 'constitutively outside' of social respectability, reinforcing through his exceptionality a notion of responsible citizenship and interpellating readers into a 'right-thinking' moral community of 'taxpayers'.

Yet what I am characterizing here as the right-wing or conservative response to Philpott was not the only one in evidence across the British newspapers in the wake of the guilty verdict. The Daily Mirror's framing of the Philpott case, for example, was divergent from - if not quite oppositional to - that of the newspapers mentioned above. This might be expected, given the Mirror's somewhat left-of-centre ideological stance: once known for its reports about the everyday lives of working-class people, the Mirror's core readership consists of Labour, rather than Conservative Party supporters (Freedman 2009: 62), and while the newspaper today is often known for its populism and celebrity gossip, it adopted a counter-hegemonic position against the invasion of Iraq (although its anti-war stance was more muted 
once the war had begun) (2009: 66). The Mirror's reporting of the story was marginally less judgemental and its thematic concerns differed from those of the newspapers discussed above.

On the day of the verdict, the Mirror certainly joined in the general tabloid condemnation of Philpott. An editorial on page 10 ('True Monster') is short and uncompromising, opining that 'there are few words strong enough to describe the depravity of evil Mick Philpott'. The headline on the front page is 'Pure Evil' and the word 'evil' recurs in the second paragraph of the frontpage story. Like the Express and other conservative newspapers, the Mirror prefixes Philpott's name with an epithet, in this case 'Wicked'. The accompanying photograph, which dominates the left-hand side of the front page, is an enlarged headshot of Philpott looking to one side with what could be read as a furtive or disdainful facial expression, reinforcing a sense of Philpott's calculating depravity. The front-page story is followed by several double-page spreads. The first of these is captioned 'Guilty: Britain's most evil dad' (Fricker and Rossington 2013: 4-5) and is illustrated by several photographs: one of Philpott with the six children and several of the burnt-out interior of the house. The Mirror, like the Express, mentions that Philpott had participated in a karaoke session only days after the killings, although this information is found only several paragraphs into the spread on page 4 , rather than appearing near the start, as in The Express, indicating the Mirror's less sensationalizing approach. More significantly still, the Mirror entirely avoids the right-wing newspapers' concern with the extent of the Philpotts' benefit claims.

A second double-page spread on pages 6 and 7 of the Mirror is devoted to the story of Philpott's ex-lover Heather Kehoe ('Victim 1'), who talks about her abuse at the hands of Philpott, while another woman ('Victim 2') talks of how she was raped by Philpott in a 'dirty' and 'squalid' caravan outside his house in 2005. This story ends with the woman's prediction that Philpott will be attacked in jail: 'They'll get him. I can't wait'. A final double spread on pages 8 and 9 of the Mirror introduces readers to 'Victim 3', Philpott's ex-fiancé Kim Hill, whom Philpott abused and on one occasion stabbed repeatedly (Smith and Fricker 2013: 8-9). Hill's was a story that the Philpott jury had not been allowed to hear for legal reasons. The three victims are all presented as 'innocent' and defenceless and thus conform to the category of 'ideal victims', in Christie's (1986: 18) typology, that is, individuals who feature at the top of the 'hierarchy of victimization' (Greer 2003: 22-23). Often, when women are turned to as news sources, it is as victims of crimes and usually their voices are heard only after the story has been introduced and commented upon by more 'authoritative' male voices (Carter 1998: 227). Both of these situations pertain in this case; nevertheless, the Mirror did more than any of the newspapers discussed above to relay the stories of Philpott's earlier victims in their own words.

The Mirror's account of Philpott's attack on Hill is accompanied by a large screenshot of Mick and Mairead's infamous appearance on the ITV television talk show The Jeremy Kyle Show. This concentration on Philpott's Jeremy Kyle appearance - typical of the intertextual aesthetics of tabloid newspapers is developed in the same edition by Allison Phillips (2013: 15), in a column entitled 'Twisted Philpott freakshow shames all of us'. Phillips's article excoriates the 'celebrity culture' that allowed Philpott to become an icon for the 'Jeremy Kyle generation'. For Phillips, we are all to blame for turning Philpott into an idol and for paying prurient attention to his antics, while ignoring the plight of their children. A flaw in Phillips's argument, perhaps, is that Philpott 
was widely reviled rather than lionized at the time of his media appearances; in fact, as Phillips herself notes, Philpott's appearance on The Jeremy Kyle Show had elements of a latter day 'freak show' and Philpott was derided by the audience for his feckless 'lifestyle'; this ensured that Philpott came pre-coded as a 'scrounger' when the house fire verdict was announced. Nevertheless, Phillips does not directly attack Philpott on the grounds that he is a 'benefits scrounger'; still less does she imply that his crimes were caused by his dependence on benefits. Rather, she frames his crimes in terms of a breakdown in social values, or what she calls the 'ills of contemporary society'. As she writes,

the world has always had men like Philpott: idle, feckless, motivated by sex and booze and manipulating of those around them. But just a generation ago men like him would have been shunned. There would have been no pride attached to their indolent lifestyle.

Despite her description of Philpott as 'feckless' - a word often collocated with 'scroungers' - and her reference to Philpott's indolence, Phillips ends her article by explicitly disavowing the connection between the Philpott's crime and his exploitation of the benefits system: 'no matter what our government and their like might have you believe, Mick Philpott wasn't representative of a generation of people living on benefits. He was representative of Mick Philpott' (Phillips 2013: 15).

Like the conservative press, the Mirror sought to-link Philpott's crime to wider cultural trends; indeed, all of the newspapers discussed above tended to follow the melodramatic tabloid convention of treating crime as a 'didactic drama, designed to teach the audience a lesson' (Gripsrud 1992: 87). But the focus of this didacticism is different in each case. For the Mail, Express and other conservative newspapers, Philpott's crime is symptomatic of a corrupting 'benefits culture'; for the more left-leaning Mirror, celebrity culture - and the public's investment in it - is the real problem. These different framings are clearly correlated to the newspapers' respective political affiliations. The rightwing newspapers predictably supported the Conservative Party, whose leading figures, notably the Chancellor George Osborne, connected Philpott with a putative 'something for nothing' culture. The Labour-supporting Mirror, meanwhile, lost no time in condemning Osborne for making this connection and exploiting a tragedy for political gain. The Mirror also devoted far greater attention to the female victims of Philpott than the conservative press.

The Guardian, another generally Labour-supporting newspaper, adopted a less condemnatory tone in its reporting of the Philpott verdict. Although the newspaper's front-page coverage does mention the word 'evil', it does so only via a quotation made by the sentencing judge (Dodd and Laville 2013: 1). Some Guardian commentators, meanwhile, questioned the exploitation of the benefits angle in the right-wing media and by right-wing politicians. Deborah Orr (2013: 35), for example, asks why the Philpott's crime has been attributed to 'welfare culture' rather than a host of other possible causes. (Indeed, the attempt to link Philpott's crime to his 'benefit dependency' was thoroughly ideological: given that Philpott had once been in the army, his crime might have been understood in terms of the damaging effects of military training on his state of mind; but such a framing would hardly have been compatible with conservative understandings of the armed forces.) Also in The Guardian, Jonathan Freedland (2013: 39) explicitly challenged George Osborne's framing of Philpott's crime:
1. 2. 3. 4. 5. 6. 7. 8. 9. 10.

11.

12.

13.

14.

15.

16.

17.

18.

19.

20.

21.

22.

23.

24.

25.

26.

27.

28.

29.

30.

31.

32.

33.

34.

35.

36.

37.

38.

39.

40.

41.

42.

43.

44.

45.

46.

47.

48.

49.

50.

51.

52. 
48.

49.

50.

51.

52.
That was no gaffe. When George Osborne linked the sickening case of Mick Philpott - now jailed for the manslaughter of six of his own children in a house fire he started - to the state of Britain's benefits system, he knew what he was doing. A student of US politics, he was deploying a favoured technique of the American right, honed during the decadeslong culture wars. Dip your hands in the slime of an episode that stirs revulsion - and smear it all over your opponent. In the role of Willie Horton - the rapist notoriously used by Bush the elder to discredit Michael Dukakis - enter Mick Philpott. Message: if you hate him and what he did, then you ought to hate the 'benefits culture' and the Labour party that supports it.

In a similarly sceptical vein, the editor of The Independent, Chris Blackhurst (2013: 2), condemned the exploitation of Philpott's crime by right-wing journalists, arguing that it 'had nothing to do with the fact that he was liying off nearly $£ 60,000$ a year in benefits' and 'does not invite the demonisation of an entire social class'.

Local newspapers also questioned the conservative framing of the story, Darryl Hopkins (2013), in the Eastern Daily Press, warned that despite Philpott's heinous acts,

His crime is not a product of the welfare state. This case must not become a device to demonise an entire section of the most vulnerable in our society because it comes at a time when such a view is useful to those pedalling that agenda.

But among mainstream journalists it was perhaps Joyce McMillan (2013), in The Scotsman, who advanced the most radical critique of the right-wing perspective, explaining its historical precedents and its ideological utility for the British ruling elite. McMillan noted that media coverage of the Philpott case resurrected the Victorian myth of the 'undeserving poor' and risked creating a division between 'them' and 'us' - that is, between supposedly feckless, well-off 'scroungers' (a largely mythical constituency, as McMillan notes) and 'people who, like Iain Duncan Smith, are perfectly entitled to claim five-figure expenses on top of a six-figure salary'. Such views, McMillan continues,

encourage ordinary British workers to side with the wealthy against those slightly poorer than themselves and they are leading us inexorably back to the kind of world where the unemployed go hungry, and the working poor are forced to depend on charity for basic necessities.

Here McMillan takes an essentially Marxist position, arguing that the framing of Philpott as a 'scrounger' by conservative newspapers and politicians is aimed at eroding solidarity among working-class people and promoting a kind of 'false consciousness' that prevents workers from perceiving the 'real' division in British society: namely, that between workers and their rulers.

\section{CONCLUSION}

Much of the newspaper coverage of the Philpott case produced strong moral scripts around Philpott, condemning his violent acts over many years, framing these acts as 'evil' or 'wicked', and using 'dramatization, exaggeration and 
hyperbole which have been described as the main rhetorical tricks of the popular press to make the news more exciting' (Conboy 2005: 16). In line with the conservative tendency to regard surplus populations as 'human waste' (Bauman 2004), the right-wing press characterized Philpott as 'scum'. This was a highly serviceable representation of Philpott, who became what Imogen Tyler calls a 'national abject', 'an outcast that threatens from within' yet who at the same time serves to legitimize 'the prevailing order of power' (Tyler 2012: 20).

This characterization of Philpott served to depoliticize the issues raised by the Philpott case. Indeed, the language of 'evil' as deployed by crime reporters is not only sensationalizing; it also reformats crime as individual moral deficiency and obscures the social and political problems and inequalities underpinning it. This type of media coverage is thus consistent with both the individualizing tendencies of capitalist - or, as some critics prefer, 'neoliberal' (Harvey 2005) - ideology in which social security has increasingly come to be understood as a privilege bestowed on individual subjects for ' good behaviour' rather than a right (Wacquant 2009). Within this framework, welfare 'benefits' have become increasingly suspect - even to the point of being posited, as we have seen, as a cause of immoral behaviours. As Conservative politicians attempted to link the Philpott case to their party's 'welfare reform' agenda, the conservative press could be argued to have played a vital role as 'secondary definers' (Hall et al. 1978), framing Philpott's crime as a peculiar act of evil and thereby eliding discussion of underlying social causes and serving to reinforce the government's welfare reduction agenda.

Contesting this conservative discourse was not easy, not least because Philpott was a 'self-confessed scrounger' (Smith and Fricker 2013: 9) and the prima facie motivation for Philpott's crime was indeed to garner more social security payments. But while Philpott's desire for more social security payments may have been the proximal motive for his crime, it was not necessarily the only or even the most important one, as was recognized by some journalists. Indeed, there were significant differences between the British newspapers covering the story in terms of both content and mode of address, and alternative, critical and even radical perspectives on Philpott did emerge in the liberal press. That these perspectives emerged in newspapers with relatively modest circulations (such as The Guardian and The Independent) rather than large-circulation tabloids (such as The Daily Mail and The Sun) reflects the weight of dominant ideology in capitalist society. In 'a journalism environment which is institutionally and procedurally balanced towards more conservative positions' (Conboy 2004: 10), it is inevitable that Philpott's crime tended to be framed in ways that reflect hegemonic understandings of society, promote regnant political agendas surrounding welfare and de-emphasize sotidarity among working-class people.

In fact, assumptions about social class, while seldom made explicit, strongly inflected the press coverage of the Philpott case. This is, perhaps unsurprising. Lynn Hancock and Gerry Mooney (2011: 26) note that working-class people are 'frequently assumed to be more feckless, immoral and criminally-inclined than more affluent groups in popular discourse' and that 'middle class' crimes are less visible in the media than those of the working class. They also note that this double standard has combined with a wider cultural tendency in recent years to revive and remobilize the Victorian distinction between the 'deserving' and 'undeserving' poor across a range of media forms. This distinction has become an entrenched theme in British reality television. The BBC documentary programme Saints and Scroungers, for example,

1. 2. 3. 4. 5. 6. 7. 8. 9. 10. 11. 12. 13. 14. 15. 16. 17. 18. 19. 20. 21. 22. 
is centred on the 'deserving' and 'undeserving' poor distinction. Its web pages tell us: 'Dominic Littlewood follows fraud officers as they bust the benefits thieves stealing millions of pounds every year, while charities and councils track down people who actually deserve government help'. We are reminded that it is 'us' the taxpayers that are being 'robbed' by 'them'; we gain the impression that the benefits system is easy to defraud.

(Hancock and Mooney 2011: 27)

Channel 4's The Secret Millionaire - a reality programme in which wealthy undercover benefactors seek hard-working, deserving beneficiaries for a donation - is also premised upon the distinction between the deserving and undeserving poor. Indeed, to quote Hancock and Mooney again:

The ways working-class families and communities are frequently portrayed in the mass media can be read as part of an educative process; the 'normality' of middle-class lives and values are contrasted with 'dysfunctional' working class ones; 'backward looking', attitudes among the poor are rendered shameful; middle-class values associated with self-improvement and aspiration are revered. These messages reflect and forge anti-welfarism and justify other 'special measures' towards these 'problem populations'.

As the coalition government rolled out a 'benefits cap' in the summer of 2013, left-wing journalist Laurie Penny (2013), in the pages of New Statesman, excoriated the BBC's Nick and Margaret: We All Pay Your Benefits - a reality programme in which employed people are invited to spend time with and pass moral judgement on unemployed individuals - for 'pitting the underpaid against the unemployed' and 'echoing the rhetoric of the Department for Work and Pensions'. More recént reality programmes such as Super Scroungers (Channel 5, 2013) and Benefits Street (Channel 4, 2014) have presented equally controversial portraits of 'life on benefits', the latter being described by journalist and activist Owen Jones (2014: 13) as offering a 'now-predictable formula' of searching for unemployed people to 'portray in the worst possible light' and thus to 'fuel the pervasive sense that people on benefits are feckless scroungers'

The Philpott story, as told in much of the British press, clearly conforms to these patterns of representation, contributing to a situation in which, as Jones (2013: 16) claimed shortly after the Philpott verdict, 'hatred for those on benefits is out of control'. This situation depends not only on the derogation of the 'undeserving poor', but also on the careful exclusion of certain kinds of information from the media frame. For example, while the mainstream media often addresses the issue of benefit fraud, which costs the United Kingdom 1.3 billion pounds per year, little attention is devoted to the topic of tax evasion by the wealthy, which - whether fraudulent or legal - is estimated to cost Britain a far more significant 95 billion pounds per year (Milne 2012: 32).

Indeed, the tsunami of anti-welfarist propaganda surrounding the Philpott case raises the question of what quality of information the British public is provided with about the welfare system. The proposition that there is a link between claiming benefits and criminality - or, indeed, that the former leads to the latter - is particularly troubling at a time when surveys indicate 
extensive public ignorance about many aspects of the welfare benefits system. An Ipsos Morey poll whose findings were reported in July 2013 showed that the British public massively over-estimates the extent of benefit fraud (Paige 2013: 1) and it appears that British people have generally become more suspicious of benefit claimants over recent decades (Tyler 2012: 26-27). As the journalist Anne Johnstone (2013: 15) pointed out some months before the Philpott verdict was announced, 'British Social Attitudes (BSA) surveys since the early 1990s chart a hardening of attitudes towards claimants, especially the unemployed and single parents', a fact which Johnstone links to 'the ruthless demonisation of claimants by a section of the press'.

Of course, the issues and arguments addressed in this article are not uniquely British. Criticism of welfare 'scroungers' has been a feature of many national media, most notably in the United States, where the proliferation of news stories about welfare fraud can be traced back to the 1960s, at least, intensifying, as in the United Kingdom, in the 1970s (Ronald Reagan's 1976 attack on 'welfare queens' is a notorious discursive milestone). Indeed, a consideration of the US case foregrounds two discursive categories - 'underclass' and 'race' - that, while seldom explicitly mentioned in the news stories themselves, nevertheless arguably informed the reporting of the Philpott case.

In the 1980s and 1990s, the question of 'welfare dependency' in the United States became linked to the notion of the 'underclass' - a section of the US population which, according to the libertarian writer Charles Murray (1984), had become detached from the social mainstream, demoralized and disincentivized by social welfare. Indeed, as Haylett (2001: 358) notés, "“Underclass" is the ultimate expression of [the] movement towards considering claimants as beyond the bounds of "ordinary" national citizenship". Murray's characterization of the underclass resonates with the late 1990s British political discourse of 'social exclusion', which was premised on the concern that a section of British citizens was becoming 'cut off from what the rest of us regard as normal life', as New Labour's Peter Mandelson (1997: 1) put it. It also applies to the description of Mick Philpott in the conservative British press, whose journalists saw Philpott, even before his crime, as a representative of an 'underclass of roôtless, hopeless, white working-class boys' (Platell 2006: 17).

As the latter quotation implies, some of the Philpott coverage also echoes the racialized discourse surrounding the welfare-claiming underclass in the United States. Indeed, US public attitudes towards welfare have been strongly influenced by considerations of 'race' (Gilens 1996), so that, as Haylett (2001: 358) notes "the meanings of "welfare", "underclass", and "black" have acquired a degraded symbolic equivalence'. Race is, of course, a political and cultural construction rather than a 'fixed' biological feature and the boundaries constituting 'black' and 'white' (for example) are historically and politically contingent. White supremacy, for instance, has always depended upon the exclusion of certain, especially poor, 'whites' (Gillborn 2010: 6). Indeed, in countries such as the United States and Britain, middle-class white respectability is heavily premised on both 'personal responsibility and individual effort' (Gillborn 2010: 21) and 'the "backwardness" of poor white others' (Haylett 2001: 366). Working-class whites are thus often marked as grotesque and excessive, lacking the requisite cultural capital to 'succeed' and make responsible choices; working-class white women, in particular, are frequently devalued in this way (Skeggs 2005; Tyler 2008). Put simply, some populations are less 'white' than others - 'White, but not quite', in Ricky Allen's (2009) neat phrase.
1.

2.

3.

4.

5.

6.

7.

8.

9.

10.

11.

12.

13.

14.

15.

16.

17.

18.

19.

20.

21.

22.

23.

24.

25.

26.

27.

28.

29.

30.

31.

32.

33.

34.

35.

36.

37.

38.

39.

40.

41.

42.

43.

44.

45.

46.

47.

48.

49.

50.

51.

52. 
It is against this background of racialized class contempt that we must understand the reporting of recent crime stories involving working-class white British subjects, which has tended to emphasize their 'sexual promiscuity, laziness and criminality' (Gillborn 2010: 16). To take a prominent example, Karen Matthews - a white working-class woman who in 2008 staged the abduction of her daughter in the hope of making money from the ensuing publicity - was described by the Daily Mail's Amanda Platell (2008) as 'the personification of that terrifying growing phenomenon: a feckless, amoral, workshy, benefit-dependent underclass'. 'All this woman has done with her life', continues Platell, in terms that echo the right-wing condemnation of Philpott's over-reproductiveness, 'is make money out of her children. She's had seven children by five or six fathers (she's lost count) because to her, children mean cash'. While Philpott is seldom explicitly identified as 'white' in the coverage examined here, the conservative press clearly positioned him, like Matthews, as an exemplary member of a feckless and irresponsible white underclass, rendering him entirely 'other'.

Anticipating the treatment of figures such as Matthews and Philpott in the British press, Haylett (2001: 358) argues that

The incremental slide away from political support for social security benefit expenditure associated with that exchange is marked as more than an economic retreat, it is also a retreat from regarding claimants as 'people like us' - the white, moral, majority population - and has come to depend on constructing the identity of claimants in pejorative ways.

In this sense, it is possible to understand the right-wing news media's characterization of Philpott as expressive of what the journalist Julie Burchill (2005: 4) has controversially termed 'social racism'. And yet, while it is regrettable that so much of the right-wing journalism about the Philpott case seemed intended to stir up public hostility towards benefit claimants, exploiting an appalling crime in order to perpetuate an anti-welfarist agenda, these efforts were challenged in newspapers with more liberal perspectives - a finding consistent with evidence from other national contexts (see, e.g. Renvall and Vehkalahti 2002).

\section{REFERENCES}

Allen, Ricky L. (2009), 'What about poor whites?' in William C. Ayers, Therese Quinn and David Stovall (eds), Handbook of Social Justice in Education, New York: Routledge, pp. 209-30.

Bauman, Z. (2004), Wasted Lives: Modernity and Its Outcasts, Cambridge: Blackwell.

Blackhurst, C. (2013), 'It's not easy speaking in measured tones about Philpott', The Independent, 6 April, p. 2.

Burchill, J. (2005), 'Yeah but, no but, why I'm proud to be a chav', The Times 2, 18 February, p. 4.

Carter, C. (1998), 'When the extraordinary becomes ordinary: Everyday news of sexual violence', in Cynthia Carter, Gill Branston and Stuart Allan (eds), News, Gender and Power, London and New York: Routledge, pp. 219-32.

Cavendish, C. (2013), 'Did welfare create this monster? The benefits system entrenches people in unemployment and unwittingly encourages them to lie, cheat and have big families', The Sunday Times, 7 April, pp. 21-22. 
Chermak, S. (1995), Victims in the News: Crime and the American News Media, 1. Boulder, CO: Westview Press.

Chibnall, S. (1977), Law and Order News: An Analysis of Crime Reporting in the British Press, London: Tavistock.

Christie, N. (1986), 'The ideal victim', in E. Fattah (ed.), From Crime Policy to Victim Policy: Reorienting the Justice System, Basingstoke: Macmillan, pp. 17-30.

Cohen, S. (1972), Folk Devils and Moral Panics, London: MacGibbon and Kee.

Conboy, M. (2004), Journalism: A Critical History, London: Sage.

- (2005), Tabloid Britain: Constructing a Community through Language, London: Routledge.

Deacon, A. (1978), 'The scrounging controversy: Public attitudes towards the unemployed in contemporary Britain', Social and Economic Administration, 12: 2, pp. 120-35.

Dodd, Vikram and Laville, Sandra (2013), "Evil, stupid and shameful" parents guilty of fire deaths: Philpotts and friend killed six children in twisted plot that went wrong', The Guardian, 3 April, p. 1.

Entman, Robert M. (1993), 'Framing: Toward clarification of a fractured paradigm', Journal of Communication, 43: 4, pp. 51-58.

Ferrari, N. (2013), 'Scum total of all that's wrong with Britain', Sunday Express, 7 April, p. 25.

Freedland, J. (2013), 'Labour must draw the sting from welfare, or lose in 2015', The Guardian, 6 April, p. 39.

Freedman, D. (2009), "Smooth operator": The propaganda model and moments of crisis', Westminster Papers in Communication and Culture, 6: 2, pp. 59-72.

Fricker, M. and Rossington, B. (2013), 'Killer's 6 kisses', The Mirror, 3 April, pp. 4-5.

Garthwaite, K. (2011), "“The language of shirkers and scroungers?" Talking about illness, disability and coalition welfare reform', Disability $\mathcal{E}$ Society, 26: 3, pp. 369-72.

Gilens, M. (1996), "Race coding" and white opposition to welfare', The American Political Science Review, 90: 3, pp. 593-604.

Gillborn, D. (2010), The white working class, racism and respectability:

Victims, degenerates and interest-convergence', British Journal of Education Studies, 58: 1, pp. 3-25.

Golding, P. (1999), Thinking the unthinkable: Welfare reform and the media', in Bob Franklin (ed.), Social Policy, the Media and Misrepresentation, London: Routledge, pp. 146-56.

Golding, P. and Middleton, S. (1982), Images of Welfare: Press and Public Attitudes to Poverty, Oxford: Martin Robertson.

Greer, C. (2003), 'News media, victims and crime', in Pamela Davies, Peter Francis and Chris Greer (eds), Victims, Crime and Society, London: Sage, pp. 20-49.

Gripsrud, J. (1992), 'The aesthetics and politics of melodrama', in Peter Dahlgren and Colin Sparks (eds), Journalism and Popular Culture, London: Sage, pp. 84-95.

Hall, S. et al. (1978), 'The social production of news', in Paul Marris and Sue Thornham (eds), Media Studies: A Reader, 2nd ed., New York: New York University Press, pp. 645-52.

Hancock, L. and Mooney, G. (2011), 'Saints and scroungers: Constructing the poverty and crime myth', Criminal Justice Matters, 83: 1, pp. 26-27.

2.

3.

4.

5.

6.

7.

8.

9.

10.

11.

12.

13.

14.

15.

16.

17.

18.

19.

20.

21.

22.

23.

24.

25.

26.

27.

28.

29.

30.

31.

32.

33.

34.

35.

36.

37.

38.

39.

40.

41.

42.

43.

44.

45.

46.

47.

48.

49.

50.

51.

52. 
Harvey, D. (2005), A Brief History of Neoliberalism, Oxford: Oxford University Press.

Haylett, C. (2001), 'Illegitimate subjects? Abject whites, neoliberal modernization and middle-class multiculturalism', Environment and Planning D: Society and Space, 19: 3, pp. 351-70.

Hopkins, D. (2013), 'A shameless man but', Eastern Daily Press, 5 April.

'In the gutter' (2013), [editorial] The Sun, 3 April, p. 8.

Jeeves, P. (2013a), '6 angels killed by evil parents', The Express, 3 April, p. 1.

_ (2013b), 'Killer dad started blaze so he could get more benefits', The Express, 3 April, pp. 4-5.

Johnstone, A. (2013), 'Where is sympathy for least fortunate?' The Herald (Features), 18 February, p. 15.

Jones, O. (2012), Chavs: The Demonization of the Working Class, London: Verso. - (2013), 'Hatred of those on benefits is dangerously out of control', The Independent, 18 May, p. 18.

— (2014), 'Benefits Street is prejudiced, distorted and divisive. It's also just the latest in a long line of TV exploitations of the poor', The Independent, 9 January, p. 13.

Mandelson, P. (1997), Labour's Next Steps: Tackling Social Exclusion, London: Fabian Society.

McMillan, J. (2013), 'Myth of undeserving poor revisited', The Scotsman, 5 April, p. 29.

Milne, S. (2012), 'A roll call of corporate rogues who are milking the country: The scale of unpaid tax now outstrips the entire deficit', The Guardian (Comment and Debate), 31 October, p. 32.

Murray, C. (1984), Losing Ground: American Social Policy 1950-1980, New York: Basic Books.

Orr, D. (2013), 'If welfare is to blame for Philpott's crimes, so is the army, feminism, prison .... The Guardian, 6 April, p. 35.

Paige, J. (2013), 'British public wrong about nearly everything, survey shows; Research shows public opinion often deviates from facts on key social issues including crime, benefit fraud and immigration', The Independent, 9 July, p. 1.

Pearson, A. (2013), 'Mick Philpott, a good reason to cut benefits; Something has gone awry when skivers like Mick Philpott feel all-powerful and society cannot summon the moral will to say "No. Enough", The Daily Telegraph, 3 April.

Penny, L. (2013), 'The BBC is colluding in the government's attack on benefit claimants', New Statesman, 22 July.

Phillips, A. (2013), 'Twisted Philpott freakshow shames all of us', The Mirror, 3 April, p. 15.

Platell, A. (2006), Never mind "Shameless Mick", what about his women?' Daily Mail, 18 November, p. 17.

_ (2008), 'Shannon's mother and seven babies by six men', Daily Mail, 6 December, p. 19. - (2013), 'What took you so long to cotton on, George', Daily Mail, 6 April.

Pritchard, D. and Hughes, Karen D. (1997), 'Patterns of deviance in crime news', Journal of Communication, 47: 3, pp. 49-67.

Renvall, Mika and Vehkalahti, Pertti (2002), "The unemployed as "others" in welfare journalism', Nordicom Review, 23: 1-2, pp. 251-62. 
Skeggs, B. (2005), 'The making of class and gender through visualizing moral subject formation', Sociology, 39: 5, pp. 965-82.

Smith, L. and Fricker, M. (2013), 'I'll never forget his eyes as he knifed me 27 times ... Mick is a monster', The Mirror, 3 April, pp. 8-9.

Tyler, I. (2008), 'Chav mum, chav scum', Feminist Media Studies, 8: 1, pp. 17-34.

(2012), Revolting Subjects: Social Abjection and Resistance in Neoliberal Britain, London: Zed Books.

Wacquant, L. (2009), Punishing the Poor: The Neoliberal Government of Social Insecurity, Durham, NC: Duke University Press.

Wahl, O. (1995), Media Madness: Public Images of Mental Illness, New Brunswick, NJ: Rutgers University Press.

1. 2. 3. 4. 5. 6. 7. 8. 9. 10. 11. 12. 13.

\section{SUGGESTED CITATION}

Harper, S. (2014), 'Framing the Philpotts: Anti-welfarism and the British newspaper reporting of the Derby house fire verdict', International Journal of Media and Cultural Politics 10: 1, pp. 79-94, doi: 10.1386/macp.10.1.79_1

\section{CONTRIBUTOR DETAILS}

Dr Stephen Harper is Senior Lecturer in Media Studies at the University of Portsmouth. His research inferests include propaganda, cultural images of war, British television drama and documentary, and the mediation of mental distress. He has written many journal articles and book chapters on these and other subjects and is the author of the books Madness, Power and the Media (Palgrave 2009) and Beyond the Left: The Communist Critique of the Media (Zero 2012).

Contact: Senior Lecturer in Media Studies, School of Creative Arts, Film and Media, University of Portsmouth, Eldon Building North Wing, Winston Churchill Avenue, Portsmouth PO1 2DJ.

E-mail: stephen.harper@port.ae.uk

Stephen Harper has asserted his right under the Copyright, Designs and Patents Act, 1988, to be identified as the author of this work in the format that was submitted to Intellect Ltd.
14.

15.

16.

17.

18.

19.

20.

21.

22.

23.

24.

25.

26.

27.

28.

29.

30.

31.

32.

33.

34.

35.

36.

37.

38.

39.

40.

41.

42.

43.

44.

45.

46.

47.

48.

49.

50.

51.

52. 